\title{
What Are the Implications of Climate Change for Retrofitted Historic Buildings? A Literature Review
}

\author{
Lingjun Hao ${ }^{1,2, * \mathbb{C}}$, Daniel Herrera-Avellanosa ${ }^{2}$, Claudio Del Pero ${ }^{1}\left[\right.$ and Alexandra Troi ${ }^{2}$ \\ 1 Department of Architecture, Built Environment and Construction Engineering, Politecnico di Milano, \\ 20133 Milano, Italy; Claudio.delPero@polimi.it \\ 2 Institute for Renewable Energy, Eurac Research, 39100 Bolzano, Italy; Daniel.Herrera@eurac.edu (D.H.-A.); \\ Alexandra.Troi@eurac.edu (A.T.) \\ * Correspondence: Lingjun.Hao@polimi.it
}

Received: 7 August 2020; Accepted: 11 September 2020; Published: 14 September 2020

\begin{abstract}
Historic buildings account for more than one-quarter of Europe's existing building stock and are going to be crucial in the achievement of future energy targets. Although a drastic reduction in carbon emissions would slow climate change, an alteration in the climate is already certain. Therefore, the impact of climate change on retrofitted historic buildings should be considered in terms of occupants' comfort, heritage conservation, and energy performance. Inappropriate interventions might weaken the potential of traditional climate adaptive solutions, such as thermal mass and night cooling, leading to higher risks of overheating in a warming climate. Similarly, retrofit solutions will change the moisture dynamics of historic envelopes, which might lead to moisture damages when combined with more extreme precipitation events. This paper reviews recent literature that provides evidence of climate change's impact on retrofitted buildings, reveals potential future risks, and thereby sheds light on new factors influencing the decision-making process in the retrofit of historic buildings.
\end{abstract}

Keywords: historic buildings; energy retrofit; climate change; internal climate; overheating; moisture risks

\section{Introduction}

The severity and the impact of climate change have been rigorously assessed in scientific literature. According to IPCC's (Intergovernmental Panel on Climate Change) Fifth Assessment report [1], the increase of global surface temperature by the end of the 21st century is expected to exceed 2.6-4.8 ${ }^{\circ} \mathrm{C}$ compared to 1986-2005 in the most pessimistic scenario. Together with this temperature increase, extreme climate events are expected to occur more frequently. For instance, the length, frequency, and intensity of heatwaves might increase in large parts of Europe, Asia, and Australia. It is also likely that "extreme precipitation events will become more intense and frequent in many regions" [1]. The EEA (European Environment Agency) also confirmed this tendency [2]. However, the changes among different regions will not be uniform. Heavy precipitations are likely to become more frequent in most parts of Europe, especially in Scandinavia and Eastern Europe in winter.

Climate change is an increasing challenge for the conservation of the built heritage. It could lead to accelerated degradation or loss of cultural heritage [3], due to continuous degradation or destructive climatic events. Weather- and climate-related natural hazards, such as river/coastal floods, landslides, wildfires, etc., could cause catastrophic loss of historic buildings. Buildings exposed to natural hazards attract much attention because of the immediacy of the losses. On the other hand, cumulative degradation risks are increasing due to climate change. For instance, the temperature increase in winters could lead to a higher prevalence of insect pests and fungal attack, warping of 
timber elements, staining, and discoloration of masonry [4]. In this regard, cumulative degradation-risk assessment and adaptation are necessary to ensure buildings' resilience to new climate conditions.

Since the change of the century, several European projects studied the impact of climate change on historic buildings. For instance, the European project NOAH'S ARK [5] defined the meteorological parameters that are critical to the built heritage and developed a vulnerability atlas and a guideline to prepare structure and materials for future risks. On this basis, the CLIMATE FOR CULTURE project [6] enhanced the risk prediction method with high-resolution climate models and whole building simulation for specific regions. NANOMATCH [7] aimed at producing nanostructured materials for historic materials under the climate change context, and PARNASSUS [8] focused on the impact of future flooding and wind-driven rain on historic buildings due to climate change and the validation of adaptation measures. Nowadays, researchers from the ADAPT NORTHERN HERITAGE project [9] are working on the identification of possible adaptation activities for heritage sites in the Northern Periphery and Arctic. These projects confirmed the relevance of investigating the impact of climate change on historic buildings. The studies looked into the consequences of higher temperatures, shifting precipitation patterns, higher flooding risks, and rising sea levels, which will influence heritage conservation, energy performance, and retrofit decisions. However, all these studies considered historic buildings in their original state, that is, before any energy improvement intervention.

To limit climate change and guarantee energy security, increasing attention is paid to the energy retrofit of historic buildings. In fact, the construction sector contributes $18.4 \%$ of total global anthropogenic GHG (greenhouse gas) emissions [1]. Historic buildings constitute a considerable share of building stocks in Europe since more than 14\% of existing buildings were built before 1919, 12\% were built between 1919 and 1945 [10], and around 40\% were made before 1960 [11]. Residential buildings constitute $22.7 \%$ of the buildings built before 1945 , and the share of residential buildings built between $1945-1969$ is $26.2 \%$ [12]. Most of these historic buildings have not undergone any energy retrofit. The average U-value of walls in residential buildings built before 1945 is $1.45 \mathrm{~W} / \mathrm{m}^{2} \mathrm{~K}$, and $1.39 \mathrm{~W} / \mathrm{m}^{2} \mathrm{~K}$ for the walls in residential buildings built between 1945-1969 [13]. As a result, the average energy consumption in historic buildings is considerably higher than in modern buildings [11]. It is estimated that the renovation of European dwelling stock built before 1945 could save up to $180 \mathrm{Mt}$ of $\mathrm{CO}_{2}$ per year afterward [10] and improve the thermal comfort of occupants.

Carbon emission and sustainability targets call for more efficient buildings. This implies demolishing and reconstructing new buildings or implementing retrofit solutions in the existing stock. In the debate of "demolish" vs. "retrofit", the environmental benefits of retrofitting historic buildings have been proved using an LCA (Life Cycle Assessment) approach. From a sustainability point of view, existing buildings already embody the energy used in the construction process, including resource extraction, transportation to the plant, and manufacture of construction materials. [14]. The embodied energy of the construction process could amount to up to $30 \%$ of the whole life cycle energy consumption [15]. With demolition, the embodied energy would be discarded. Therefore, preserving historic buildings is in itself sustainable, not to mention that historic, cultural and aesthetic values protected. It is important to highlight that, in the case of historic buildings, preservation principles should be as important as energy efficiency and emission targets [16].

Despite the environmental benefits and urgency, the renovation rate of historic buildings is still very low. In Europe, the average total rate of energy renovations which achieve more than a $3 \%$ primary energy saving in residential buildings was only 5.2\% during 2012-2016 [17]. In the renovation building stock, the share of buildings renovated to nearly zero energy building standard was $17.5 \%$ in 2016 [17]. One of the barriers to climate change mitigation in the built heritage sector is the compatibility of retrofit solutions with the historic fabric [18]. Retrofit interventions can change the building's performance substantially, from indoor climate to the envelope's moisture dynamics $[19,20]$.

Although a drastic reduction in the carbon emissions would slow climate change, some alteration in the climate is already certain, and therefore the impact of future climate should be considered when retrofitting a historic building. Combined with a changing climate, inappropriate choices of retrofit 
solutions might further endanger building conservation and weaken the building's performance. As a consequence, there is a need to investigate the performance of the retrofitted historic buildings in the context of climate change. However, there are no review studies focusing on this topic. Some studies summarized the method and techniques used in energy retrofit of historic buildings [21,22] or the criteria to assess and select the optimal solutions [23,24]. Some studies pay attention to specific topics. For instance, Sofia Lidelöw et al. discussed how heritage values are analyzed and approached in energy retrofit practices [25]. Fredrik Berga et al. reviewed research agenda and identified the key barriers in integrating user behavior to energy retrofit [26].

This paper first defines the relevant concepts and introduces historic building-related policies on climate change mitigation and adaptation. Then, a review of recent literature is presented, providing evidence of the combined impacts of climate change and energy retrofit on historic buildings. Ultimately, potential future risks are highlighted together with the future research needed. The impacts are summarized into three aspects: energy consumption, indoor climate, and building conservation. A systematic keyword search in scientific databases (e.g., Scopus), a common methodology for literature review [21,27], is used in this paper to identify and analyze recent articles. A combination of terms is possible thanks to the use of key terms (including synonyms) and Booleans like "OR" and "AND". The search query used was "historic building" or "built heritage" or "traditional building" or "historic center" or "historic district" and "climate change" or "future climate" and "(energy) retrofit" or "renovation" or "internal insulation" and "overheating" or "thermal comfort" or "thermal mass" or "ventilation" or "passive cooling" or "energy (efficiency)" or "(wind-driven) rain" or "building conservation" or "hygrothermal performance".

\section{Concepts and Related Policies}

Historic buildings are defined in this paper in line with the scope of European standard EN 16883:2017 Conservation of cultural heritage-Guidelines for improving the energy performance of historic buildings [28]. That is, a historic building does not necessarily have to be formally "listed" or protected; therefore, the definition refers to any building that is worth preserving. At the same time, retrofit refers to the modification of the existing configuration, aimed at improving the building's conditions to an acceptable level while minimizing energy consumption.

Mitigation and adaptation are two main policy responses to climate change. Climate change mitigation refers to the efforts to limit global warming through cutting GHG emissions. EU-wide, the climate-energy policy framework has been developed to mitigate climate change since the early 1990s [29]. In 2009, the "Climate and energy package" set three main targets: 20\% cut in greenhouse gas emissions (from 1990 levels), 20\% of EU energy from renewables, and 20\% improvement in energy efficiency [30]. Moreover, the EU renewed its commitment to the goal of keeping global warming below $2{ }^{\circ} \mathrm{C}$ above pre-industrial levels. Heads of State and Government also formally adopted the objective to reduce emissions by $80-95 \%$ by 2050 in comparison to 1990 levels.

In the building sector, several directives are issued to improve the energy performance of both new and existing buildings. In EPBD 2002/91/EU [31], a minimum energy performance is defined, but the Member States are in charge of the detailed implementation. After that, EPBD Recast 2010/31/EU [32], the standards to calculate energy performance and the compulsory energy certification, are formulated. To fulfil the energy requirements, the directive also introduced the nearly zero-energy building (NZEB) concept. Member States should ensure that by the end of 2020, all new buildings are NZEBs. Directive 2012/27 [33] establishes a common framework in order to ensure the achievement of the $20 \%$ headline target on energy efficiency. To fulfill the target, Member States shall establish a long-term strategy for mobilizing investment renovation, and public bodies' buildings should play an exemplary role. More specifically, $3 \%$ of the total floor area of heated and/or cooled public buildings must be renovated annually to meet the minimum energy performance requirements. Recast 2018/844 [34] requires the Member States to plan long-term renovation strategies and update every three years as part of the National Energy Efficiency Action Plan. All directives state that buildings officially protected because 
of their special architectural or historical merit and buildings for worship and religious activities are exempt from energy performance requirements [33].

According to EU Climate action, climate change adaptation means "anticipating the adverse effects of climate change and taking appropriate action to prevent or minimize the damage they can cause, or taking advantage of opportunities that may arise. It has been shown that well planned, early adaptation action saves money and lives later" [35]. Compared with climate mitigation policies, climate adaptation policies fall behind significantly. The Commission of the European Communities set out a first framework to reduce the EU's vulnerability to the impact of climate change in the White Paper published in 2009 [36]. It addresses the objectives and actions to increase the resilience of several sectors, including physical infrastructure. A key deliverable is the web-based European Climate Adaptation Platform (Climate-ADAPT) [37]. After that, the EU adaptation strategy was launched in 2013 [38]. It fills both knowledge and action gaps and complements these efforts through the strategy on an EU level. By creating a basis for better informed decision-making on adaptation and making key economic and policy sectors more resilient to the effects of climate change, this strategy encourages and supports Member States' action on climate adaptation.

In the building sector, the EU adaptation strategy includes a Staff Working Document [39], which provides guidance to adapt the infrastructure. It addresses the common challenges brought by climate change and the instruments on the EU level that might need to be revised. One of the most important instruments used to regulate infrastructure sectors are standards. Since 2014, the European Standardization Organizations are fostering the integration of climate change adaptation in the standardization of the construction/building sector [40].

\section{Energy Performance of Historic Buildings}

\subsection{The Implications of Changing Energy Needs}

A change in the climate will cause a change in the heating and cooling required to achieve a comfortable indoor environment. Therefore, energy consumption will vary with the changes. There is still a substantial lack of understanding when it comes to historic building stock. As shown in Table 1, there is a paucity of literature on historic buildings' energy performance in the climate change context. Most studies investigate how historic buildings could play their role in climate change mitigation instead of the impacts of climate change on their energy performance. Retrofit action is justified in a climate mitigation perspective [41], the enablers and barriers for the historic building to mitigate climate change are discussed [18,42], as well as the energy and GHG emission saving potential (Section 3.2).

Due to the increasing global temperature, heating load is decreasing in winter, while in summer, historic buildings are facing the dilemma of increasing cooling load or uncomfortable conditions [43]. The same situation has been found in the general building stock $[44,45]$, where the impact on the total energy use varies with climate zones. In the USA [46], buildings in hot climates like Houston, Miami, and San Diego will experience a net increase in primary energy needs while regions in cold or frigid weather will have a decrease. Additionally, Li et al. [47] summarized the impact of climate change on energy use in different climate zones around the world. In severely cold climates, energy use tends to decrease because the heating load reduction would outweigh the modest increase in summer cooling. In the hot summer and cold winter climate zones, the magnitude of reduction in heating and the magnitude of increase in cooling could be comparable.

The changes in energy use highlight the need for adaptation and mitigation strategies. Since the existing climate zones may change in the future [48], as well as heating and cooling degree days [49,50], any new or updated regulation should consider these changes [51]. Moreover, inadequate sizing of systems could lead to energy inefficiency or discomfort. Large variations in energy performance due to climate change are found within and between building types as well as climate zones around the world [52-55]. In a campus model of Michigan, the additional cooling energy use by the end of the 21 st century reaches $46 \%$ of the total power plant annual production, which is alarming for the 
utility [51]. However, in California, climate change only prompts modest increases in grid resource capacity (electric grid configuration on 2050) [56].

\subsection{Energy Retrofit and Building Performance}

The impact of energy retrofit on the energy performance of historic buildings has been examined previously, including of a wide range of retrofit interventions regarding envelope improvement and HVAC system updates $[57,58]$. Overall, the positive impact of retrofit on the energy performance encourages the promotion of retrofit in historic buildings. For instance, in a historic residential building built in the early 1900s in Havre (USA), an energy retrofit could achieve $81 \%$ energy saving with a payback period of 4-8 years [59]. Savings in energy consumption and carbon emissions are a dominant criterion when assessing the effectiveness of an energy retrofit [23]. Previous studies on energy consumption after retrofit confirm the importance (and limitations) of building energy simulation (BES) in assessing the impact of retrofit [23]. Another review work outlined energy retrofit impacts in different building types, and the great energy potential, between $20 \%$ and $68 \%$, in residential buildings is shown [21]. Beyond the energy performance, other topics related to the impact of retrofits in historic buildings, such as the use of new analytical tools [60] or occupancy behavior [26], are currently being investigated.

Established energy targets and the development of new energy systems urge the energy efficiency improvement of the entire built heritage [61]. Thus, the performance of the historic building stock as a whole, rather than at the individual building scale, is also explored. Some practical barriers, like the lack of local plans, the lack of coordination and integration among local planning instruments, or the lack of knowledge of the actual energy situation and intrinsic value of heritage [62,63], are limiting the implementation of retrofit at a wider scale. Indicators like EPC (Energy Performance Certificates), vacant ratio, and building age [64] have been used to overcome these barriers. With a similar bottom-up method, Csoknyai et al. developed and compared seven residential building typologies from four countries in Eastern Europe and found that the energy-saving potential achieved with deep renovation of buildings built before 1945 ranges between $60.4 \%$ and 79.8\% [65]. Most Urban Building Energy Modelling (UBEM) relies on typical building typologies or archetypes to represent the most frequent categories in the stock. In [66], an attempt is made to implement heritage value into the building archetypes to improve their reliability. Alternatively, a top-down approach is used to perform the GHG balancing of the medieval historic center of Siena (Tuscany, Italy) in [67]. The results show that the installation of photovoltaic panels on roofs (outside the medieval district) could enable the carbon neutrality of the historic center in about 30 years.

The aforementioned literature focused on the method, technique, assessment, or selection of retrofit solutions according to the energy performance, while climate change as a significant influencing factor is not considered (Table 1).

Table 1. Main literature on building energy performance. $\mathrm{HB}=$ Historic building specific, $\mathrm{RB}=$ Retrofitted building specific, $\mathrm{CC}=$ Climate change considered.

\begin{tabular}{rccccc}
\hline No. & Region/Country & HB & RB & CC & Content/Main Finding \\
\hline$[43]$ & $\begin{array}{c}\text { Prague, Czech } \\
\text { Republic }\end{array}$ & Yes & Yes & Yes & $\begin{array}{c}\text { Cooling demand increases due to } \\
\text { climate change }\end{array}$ \\
\hline$[44]$ & Adelaide, Australia & No & Yes & Yes & $\begin{array}{c}\text { Climate change shifts energy } \\
\text { demand, cooling becomes } \\
\text { dominant in the dimensioning }\end{array}$ \\
\hline$[45]$ & Växjö, Sweden. & No & No & Yes & $\begin{array}{c}\text { Overheating increases in climate } \\
\text { change scenarios }\end{array}$ \\
\hline
\end{tabular}


Table 1. Cont.

\begin{tabular}{|c|c|c|c|c|c|}
\hline No. & Region/Country & HB & RB & $\mathrm{CC}$ & Content/Main Finding \\
\hline [46] & $\begin{array}{l}\text { Several climate zones } \\
\text { in USA }\end{array}$ & No & No & Yes & $\begin{array}{l}\text { Energy use changes in different } \\
\text { climate zones due to climate } \\
\text { change }\end{array}$ \\
\hline [48] & $\begin{array}{l}\text { Several climate zones } \\
\text { in China }\end{array}$ & No & No & Yes & $\begin{array}{l}\text { Changes in energy use and } \\
\text { climate zones due to climate } \\
\text { change }\end{array}$ \\
\hline [59] & Havre, USA & Yes & Yes & No & $\begin{array}{l}\text { Strong energy and economic } \\
\text { justifications of retrofit }\end{array}$ \\
\hline [61] & Sece, Latvia & Yes & Yes & No & Novel insulation material is tested \\
\hline [65] & $\begin{array}{l}\text { Eastern-European } \\
\text { countries }\end{array}$ & Both & Yes & No & $\begin{array}{l}\text { A detailed comparative analysis } \\
\text { of residential building stock of } \\
\text { Eastern-European countries }\end{array}$ \\
\hline [57] & Italy & Yes & Yes & No & $\begin{array}{l}\text { The same retrofit action will be } \\
\text { invalid when in mismatched } \\
\text { climate zone }\end{array}$ \\
\hline [58] & Seoul, Korea & Yes & Yes & No & $\begin{array}{c}\text { The effect of energy efficiency } \\
\text { measure packages in an office and } \\
\text { a museum is analyzed }\end{array}$ \\
\hline
\end{tabular}

\section{Internal Climate of Historic Buildings: Comfort and Energy}

A building's envelope is the interface between indoor and outdoor environments. Besides thermal conductivity, the two main interactive processes that are controlled by this interface and that influence the indoor climate are thermal inertia and air exchange. Temperature in "free-running" buildings is closely dependent on outside temperature because of their reliance on passive strategies $[68,69]$. Thermal mass, which refers to construction mass that could store heat, is a passive climate regulation strategy commonly found in historic buildings. They are usually featured with high heat capacity materials such as bricks, natural stone, and tiles [70]. A large body of literature has verified the thermal inertia effect of thermal mass and its benefits for the internal thermal comfort [71-73]. Passive cooling effects combining thermal mass and natural ventilation, especially night ventilation, could remove excess heat to maintain a comfortable temperature during summer. For example, Gagliano et al. [74] verified that thermal mass and ventilation in historic buildings could reduce cooling demand by $30 \%$ in a moderate climate. Many investigations showed the principle and effect of night cooling to reduce surface and indoor temperatures [75-78]. However, this passive cooling technique relies heavily on buildings' thermal mass, outdoor temperature daily swing [78], solar radiation, and, ultimately, user behavior, as it has to be appropriately managed. For example, Gagliano et al. [79] suggested a time lag of 12 to $14 \mathrm{~h}$ for the east walls of a massive historic building (Catania, Italy). Any change in the climate and building will, therefore, affect the original passive solutions or imply more energy use to provide a comfortable internal climate.

\subsection{Global Warming and Historic Buildings}

Indoor climate is the result of a complex interaction of several factors, e.g., the building geometry and envelope, HVAC system, occupants, and external climate. Despite the complexity of indoor climate, the direct correlation between internal and external conditions has been largely investigated and verified. For instance, Coley et al. [80] explored the relationship between changes in internal and external temperature. The study was based on building simulations and included the dynamic representations of occupancy densities, solar gains, air densities, airflow, and heating systems. Despite this complex heat flow, a direct relationship was found fitting to a linear regression with different constants of proportionality (that is, of steepness) depending on the building types. Similarly, indoor daily mean temperature has a linear relationship to outdoor running mean temperature [81]. This linear relationship between internal and external temperatures could be used to estimate the buildings' 
resilience to climate change, and it has the potential to predict future indoor climate. In the study of the relationship between indoor and outdoor humidity, it was found that indoor absolute humidity has a strong correlation with outdoor absolute humidity all throughout the year [82]. Kramer et al. [83] established an indoor climate prediction model for historic buildings. In this model, the indoor temperature is an output of outdoor temperature and solar irradiation. Then, the indoor relative humidity is calculated on the basis of the outdoor atmospheric pressure and the modeled indoor temperature. According to these researches, the indoor climate of historic buildings is strongly related to the outdoor climate.

The impact of climate change on the indoor environment of historic buildings has been previously studied, and an increase in indoor temperature is found across Europe (e.g., The Netherlands and Belgium [84], Southern England [85], Croatia [86]). The change in indoor relative humidity differs depending on the location: it rises in the Netherlands, Belgium, and Croatia, while it shows little changes in Southern England. The growth in temperature could cause both a rise in the degradation of the collections and a decline in thermal comfort conditions. But these studies have focused on the conservation of historic artifacts rather than on the thermal comfort of the occupants. Studies on future thermal comfort are still very limited in historic buildings despite the fact that the passive cooling effect of massive walls and ventilation could fail to compensate for a future temperature rise. With climate change, there is a growing need for thermal mass and ventilation cooling, as different studies have shown. For instance, in Istanbul, the time where ventilation, high thermal mass, and evaporative cooling is needed increases from 1.4\% to 5.95\% [87]. In southern Spain, discomfort hours rise by more than $35 \%$ in social multi-family buildings built in the post-war period due to climate change [88]. Similarly, a pre-1900 dwelling in London with high thermal mass and ventilation could effectively limit the change of indoor temperature in 2005. Yet, with the external temperature increase, the average temperature of the entire house tends to be unacceptable, showing that thermal mass and ventilation cannot ensure a comfortable thermal condition any longer [89]. Adding more thermal mass may not translate into significant thermal comfort improvements [90]. Instead, an adequate ventilation strategy could make vital differences. By improving the ventilation plan, discomfort hours would be cut from $53 \%$ to $7 \%$ in 2080 in a living room of a typical 1960s building in Lisbon (Portugal) [91].

\subsection{The Role of Thermal Mass and Natural Ventilation}

Retrofit solutions also play a vital role in the configuration of the indoor climate. Pretelli and Fabbri [92] introduced several concepts to describe the indoor microclimate of historic buildings at different use phases, which emphasized the changes in indoor climate due to the retrofit interventions. With the increase in the adoption of retrofit solutions in historic residential buildings, occupants' thermal comfort should be carefully evaluated.

Internal insulation is a standard solution in the energy retrofit of historic buildings [93-95]. However, the addition of internal insulation may minimize the positive effect of thermal mass and ventilation in summer. Some investigations have looked into these drawbacks. In Cirami et al.'s [96] simulation results, the operative temperature in rooms insulated with six different retrofit solutions is always higher than an un-retrofitted historic wall on the hottest day. However, night cooling could still counterbalance the adverse effect in southern Italy. Similarly, it was found that internal insulation applied to historic masonry walls leads to a temperature rise on the internal surface of up to a $3{ }^{\circ} \mathrm{C}$ in a Mediterranean climate and, consequently, may cause overheating [97]. Moreover, the constant indoor temperature before retrofit wildly fluctuates after retrofit.

In summary, previous research has already identified the potential risk of overheating in retrofitted historic buildings. Combined with an outdoor temperature increase, overheating risk might increase significantly in retrofitted buildings in the future. In Lee et al.'s [69] dwelling case study, overheating occurs in future climates with four different construction typologies (including masonry) due to the addition of insulation. In a retrofitted Victorian house in Birmingham (UK) [98], the overheating hours could be effectively limited to $3 \%$ of the occupied hours at present with appropriate window shading 
and ventilation. In comparison, in the future, this is limited to $10 \%$ of the hours in 2050 and $22 \%$ in 2080. Without natural ventilation or solar protection, thermal mass cannot remedy the situation. However, the implementation of new solar protection features on historic façades is, in most cases, not feasible due to the need for the preservation of original historic style and features. There is still a need for further research to quantify the effect of climate change and to identify alternative retrofit solutions that prevent overheating and achieve thermal comfort both in the present and future scenarios.

Literature on the internal climate of historic buildings mainly focused on the conservation requirements of artifacts or the overheating problem caused by retrofit (Table 2). However, a relevant gap should be addressed: to optimize the indoor comfort of retrofitted buildings, the impacts of climate change and retrofit on the passive climate regulation system should be investigated.

Table 2. Main literature on internal climate. $\mathrm{HB}=$ Historic building specific, $\mathrm{RB}=$ Retrofitted building specific, $\mathrm{CC}=$ Climate change considered.

\begin{tabular}{|c|c|c|c|c|c|}
\hline No. & Region/Country & HВ & RB & $\mathrm{CC}$ & Content/Main Finding \\
\hline [80] & London, UK & No & Both & Yes & $\begin{array}{l}\text { The relationship between increases } \\
\text { in external and internal temperature } \\
\text { is studied. }\end{array}$ \\
\hline [81] & UK & Yes & Both & No & $\begin{array}{l}\text { A comparative experiment is } \\
\text { conducted between retrofit and } \\
\text { un-retrofitted historic buildings. }\end{array}$ \\
\hline [83] & $\begin{array}{l}\text { Netherlands and } \\
\text { Belgium }\end{array}$ & Yes & No & Yes & $\begin{array}{l}\text { A simplified hygrothermal model to } \\
\text { reproducing indoor climates for } \\
\text { historic buildings is presented. }\end{array}$ \\
\hline [88] & Seville, Spain & Yes & No & Yes & $\begin{array}{l}\text { A predictive model of indoor } \\
\text { comfort is generated. }\end{array}$ \\
\hline [89] & London, UK & Yes & No & Yes & $\begin{array}{l}\text { The potential of overheating in } \\
\text { different dwellings is investigated. }\end{array}$ \\
\hline [96] & Italy & Yes & Yes & No & $\begin{array}{l}\text { Overheating and mold formation } \\
\text { induced by insulation are } \\
\text { investigated. }\end{array}$ \\
\hline [97] & Italy & Yes & Yes & No & $\begin{array}{l}\text { The optimal retrofit solutions for } \\
\text { three constructions are identified } \\
\text { according to indoor comfort and } \\
\text { energy saving. }\end{array}$ \\
\hline [69] & London, UK & Yes & Yes & Yes & $\begin{array}{l}\text { A new indicator of overheating risk } \\
\text { is introduced and demonstrated } \\
\text { using a case study of a dwelling. }\end{array}$ \\
\hline [98] & Birmingham, UK & Yes & Yes & Yes & $\begin{array}{l}\text { The human behavior effect on } \\
\text { indoor comfort in future is } \\
\text { investigated. }\end{array}$ \\
\hline
\end{tabular}

\section{Moisture Dynamics in Historic Walls and Building Conservation}

The hygrothermal performance of historic building materials should be assessed before any retrofit action is implemented to ensure the compatibility of the measures proposed. D'Ayala et al. [99] monitored temperature and relative humidity in two historic walls and concluded that historical brick and mortar have different moisture absorption and desorption characteristics, even within the same building. Ultimately, the moisture content (MC) of historic walls with higher surface water absorption coefficients is more sensitive to exterior climate factors such as rain, wind, and solar radiation [100]. When high moisture conditions persist, damages like condensation, mold growth, wood decay, and frost damage may happen. Masonries with low surface temperatures are also more vulnerable to these moisture risks due to the increase of relative humidity. These low temperatures are especially found in places such as thermal bridges, corners, or cold attics [101]. Wood, generally used in historic residential buildings, is susceptible to mold growth. With suitable relative humidity and temperature, the decay 
process will start with mold growth and follow with fungal attack. Moreover, if the high moisture content continues through winter, frost damage is likely to occur.

\subsection{The Implications of Changing Precipitation Patterns}

Changes in climate factors could accelerate the erosion of detailing and construction or undermine binder and coating [4,102]. Among all climate factors, wind-driven rain (WDR) is particularly important. It can cause both surface erosion and weaken the construction. Erkal et al. [103] summarized the evidence of WDR erosion on historic façades and explored materials' response to three different diameters of raindrops. With bigger drop size, water splashes more and runs off after striking the surface. Several research studies have shown that WDR directly affects the moisture content of historic envelopes. Abuku et al. [104] compared the mold growth risk with and without WDR in a moderately cold and humid climate on the inner side of a historic brick wall. The results showed a severe risk of mold growth in summer and winter when WDR loads are considered, while there is a little risk without WDR loads. In Johansson et al.'s [105] laboratory study, a $250 \mathrm{~mm}$ wall was built to represent the real historic wall situation, and it was exposed to normal rain loads from Gothenburg (Sweden) and Bergen (Norway). The study revealed that WDR is the dominant factor determining the moisture movement in the wall. Furthermore, D'Ayala and Aktas [99] not only verified the adverse impact of WDR but also inferred that more frequent rain could be even more dangerous for the historic envelope. Nik et al. [106] simulated future moisture loads in a wooden wall and found that higher amounts of moisture will accumulate in walls in the future. Besides WDR, moisture that diffuses across the wall as vapor is another main source of moisture. Diffusion across the envelope is strongly related to indoor temperature and humidity $[107,108]$. In practice, moisture transport due to imperfection of the vapor barrier could increase the vapor transport significantly [109]. Moisture related risks of the envelope are found in buildings with large rates of moisture production or lack of ventilation [110,111]. Future changes in indoor climate could change the moisture states in historic walls. Physical models are established to facilitate the prediction and control of indoor climate in historic buildings [112-114], which could be an ideal method for investigating the impact of climate change on historic envelopes.

Mold growth negatively affects the environmental quality of the internal climate and the durability of the envelope. Different mold risk management approaches have been developed in buildings with or without active thermal controls $[115,116]$. However, climate change will impose new challenges on mold prevention. In the last 20 years, mold growth has been observed more frequently than before in ventilated attics in Sweden [117]. Temperature and humidity levels will increase in cold attics in future climate scenarios, and the risk of mold growth increases with these changes. Moreover, to retrofit the attics with insulation could decrease the condensation risk but cannot reduce the risk of mold growth. In the case of wooden structures, their durability depends on the moisture and temperature conditions as well as the exposure time. The decay of the wooden beams is usually caused by damaged downpipes, leaking roofs, and WDR [118]. With more extreme rain events in the future, the risk of water runoff along masonries due to unsuitable drainage systems will increase, while at the same time, inadequate retrofit solutions could further increase the relative humidity in the constructions.

\subsection{Fabric Improvements and Hygrothermal Performance}

Implementation of internal insulation usually changes the moisture dynamics in historic walls. In some cases, internal insulation brings extra vapor diffusion resistance, which will impede the inward drying of the wall [105]. This adverse effect is especially significant in the case of vapor-tight insulation systems. Additionally, the temperature gradient across the original wall is reduced with the addition of insulation. For instance, Odgaard et al. [119] monitored the hygrothermal performance of a historic masonry wall (with and without diffusion-open insulation) for more than two years. They found that the relative humidity of the insulated wall was $20-30 \%$ higher than that of the untreated wall. In Kehl et al.'s [118] simulations, the moisture content of wooden beams and in masonry walls is always increased when coupled with interior insulation. 
Frost damage is a mechanical weathering process caused by the water freeze-thaw cycle. Due to the changes that retrofit interventions impose on the existing structure (e.g., the lower temperature on the outer surface due to the application of internal insulation), frost damage is more likely to occur. Zhou et al. [120] proposed to use the number of actual ice growth and melt cycles as an indicator for freeze-thaw cycles. After simulations of both uninsulated and internally retrofitted brick walls, an increase of freeze-thaw cycles is found in Switzerland after internal retrofitting. Biseniece et al. [121] studied the thermal behavior of retrofitted historic buildings with two insulation materials and revealed the possibility of frost damage. As mentioned above, the frequencies and intensity of precipitation in winter may increase in many regions of Europe, which implies enhancing the risk of frost damage.

With moisture accumulation in historic envelopes, the durability of materials and thermal efficiency of the building may be endangered. To prevent this, some historic retrofit projects adopted capillary-active insulation systems that transport the moisture content [122,123]. However, the results of some investigations still show skepticism about capillary-active insulation systems. Vereecken et al. [124] compared the hygric performance of different internal insulation systems in the laboratory: vapor open, non-capillary active system, capillary-active systems, and vapor tight systems. Their results pointed out that, in the steady-state winter conditions, moisture captured by capillary-active systems is higher than by the traditional vapor-tight system. X-ray projection analysis showed that the moisture was accumulated between the glue mortar and the insulation. Klõšeiko et al. [125] also confirmed the high humidity levels in capillary-active systems (calcium silicate, aerated concrete, and polyurethane board with capillary-active channels), which increase the risk of mold growth.

Before a retrofit intervention, historic buildings are often sufficiently ventilated by uncontrolled air infiltration through old windows and doors. Any energy retrofit is likely to increase the airtightness of the envelope, which could reduce the building's capacity to remove any excess of moisture. When combined with inappropriate window operation by the occupant, risks of moisture damages could increase [111].

The response of retrofitted envelopes to climate change in specific areas remains unclear. Only a few studies have investigated historic buildings in both retrofit and future climate scenarios (Table 3).

Table 3. Main literature on moisture dynamics in historic envelopes. HB = Historic building specific, $\mathrm{RB}=$ Retrofitted building specific, $\mathrm{CC}=$ Climate change considered, $\mathrm{WDR}=$ wind-driven rain.

\begin{tabular}{|c|c|c|c|c|c|}
\hline No. & Region/Country & HB & RB & $\mathrm{CC}$ & Content/Main Achievement \\
\hline [102] & Italy & Yes & No & Yes & $\begin{array}{l}\text { An integrated method to assess and } \\
\text { predict future degradation of historic } \\
\text { building is proposed. }\end{array}$ \\
\hline [104] & Essen, Germany & Yes & No & No & $\begin{array}{l}\text { The impact of WDR on envelope's } \\
\text { hygrothermal responses is studied. }\end{array}$ \\
\hline [106] & Sweden & No & No & Yes & $\begin{array}{l}\text { The impacts of CC on WDR and walls } \\
\text { are investigated. }\end{array}$ \\
\hline [117] & Sweden & Both & Yes & Yes & $\begin{array}{l}\text { The hygrothermal performance of } \\
\text { ventilated attics impacted by CC is } \\
\text { investigated. }\end{array}$ \\
\hline [118] & Essen, Germany & Yes & Both & No & $\begin{array}{l}\text { The moisture state of wood beam ends } \\
\text { is analyzed in terms of main moisture } \\
\text { source and influencing factors. }\end{array}$ \\
\hline [119] & Denmark & Yes & Both & No & $\begin{array}{l}\text { The impact of internal insulation is } \\
\text { investigated by the analysis of } \\
\text { monitored data and risk assessment. }\end{array}$ \\
\hline [120] & Switzerland & Yes & Yes & No & $\begin{array}{l}\text { An index for freeze-thaw damage is } \\
\text { developed and the impacts of internal } \\
\text { insulation are studied. }\end{array}$ \\
\hline
\end{tabular}


Table 3. Cont.

\begin{tabular}{cccccc}
\hline No. & Region/Country & HB & RB & CC & Content/Main Achievement \\
\hline$[121]$ & Riga, Latvia & Yes & Yes & No & $\begin{array}{c}\text { The impact of internal insulation on } \\
\text { freezing risk is studied by long term } \\
\text { monitoring. }\end{array}$ \\
\hline [124] & Hot/cold box & No & Yes & No & $\begin{array}{c}\text { The hygric performance of massive } \\
\text { walls with different insulation systems } \\
\text { are compared. }\end{array}$ \\
\hline$[111]$ & Basel, Switzerland & No & Yes & No & $\begin{array}{l}\text { The impact of occupant behavior on } \\
\text { mold and condensation is assessed. }\end{array}$ \\
\hline
\end{tabular}

\section{Conclusions}

In this study, the effect of both climate change and retrofit interventions have been summarized. A changing climate will result in increased temperature and changed rain pattern; together with retrofit solutions, it may change the energy use, indoor climate, and moisture dynamic of historic buildings. In regard to energy use, the positive impact of retrofit on energy performance encourages its implementation in historic buildings as well as development of further solutions. On the other hand, variations in energy use due to changes in the future climate highlight the need for adaptation and mitigation strategies. In regard to the internal climate, overheating will be an increasing concern in the future. The combined effect of internal insulation and increased outdoor temperature may increase energy demand for cooling. In regard to moisture dynamics in the historic envelope, moisture risks are more likely to occur due to changes in the external climate (e.g., changed precipitation pattern) and subsequent changes in the indoor climate. Considering that retrofit interventions could reduce the drying capacity of the walls and modify the temperature gradient, and the combined effect of a changing climate and retrofit interventions could undermine the conservation of the historic envelopes.

Literature in four different research fields on historic buildings, directly linked to climate and retrofit scenarios (Figure 1), is reviewed. Literature on general building stock is added if the literature specific to historic buildings is too scarce. The results show that the impacts of climate and retrofit on performance can be summarized into three main aspects: energy use, indoor comfort, and moisture dynamics in the envelopes. Therefore, it is necessary to establish a multi-criteria approach for the selection of retrofit interventions. The study of the combined impacts is still very limited (Field-iv in Figure 1). To close this gap, historic buildings' performance-i (current and un-retrofitted scenario) and performance-ii (current and retrofitted scenario) should be compared to assess the impacts of current retrofit solutions. With this knowledge, the additional impact of climate change could be assessed by comparison of historic buildings' performance-ii (current and retrofitted scenario) and performance-iv (future and retrofitted scenario). Through these studies, the role of thermal mass and natural ventilation in future scenarios and the relationship between the moisture state of a historic building, rain pattern changes, and retrofit solutions could be further evaluated. Ultimately, deepening knowledge on these topics will allow better informed decisions as they will provide a better understanding of future risks to energy efficiency, occupants' thermal comfort, and building conservation. 


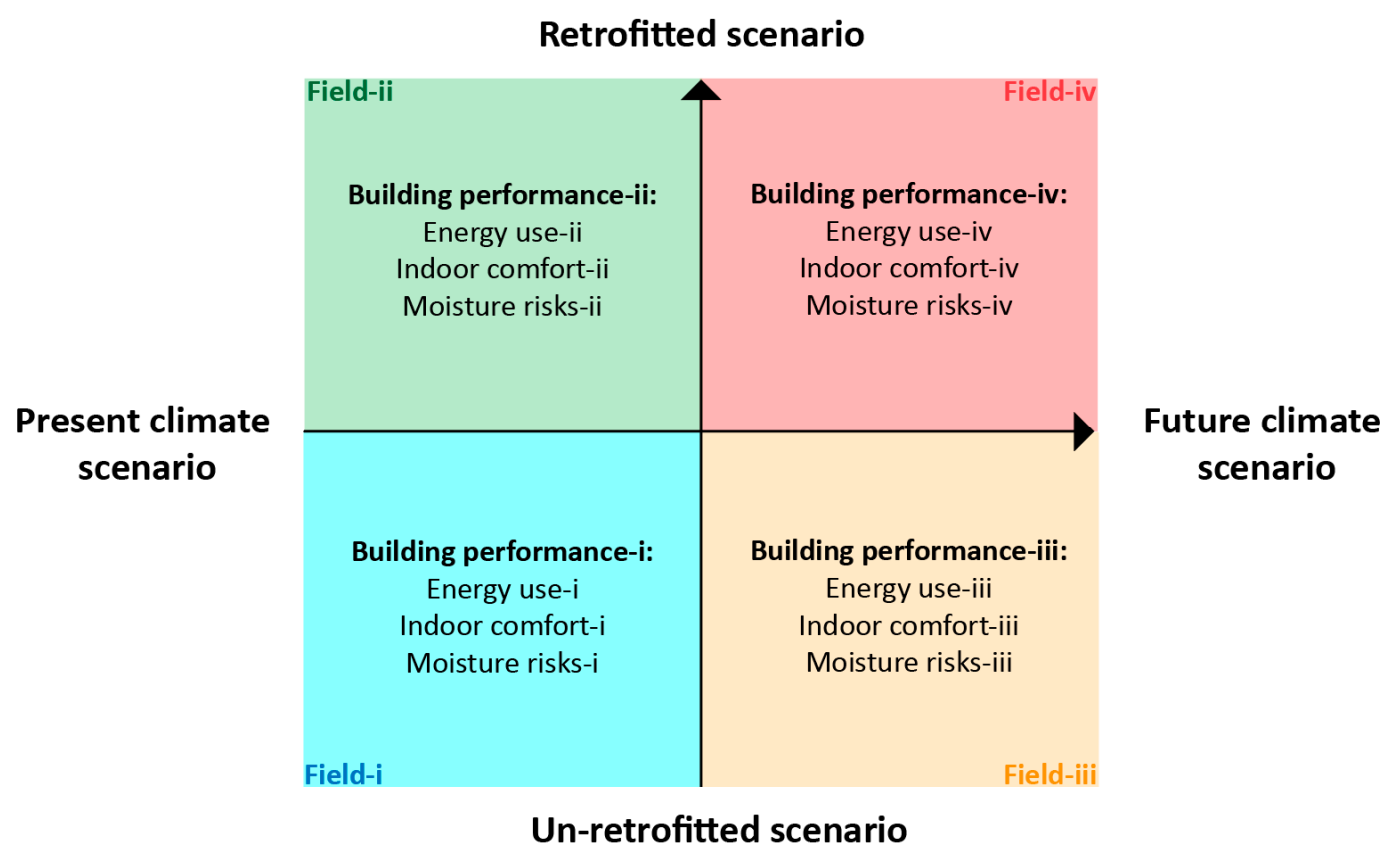

Figure 1. Research fields of historic buildings coordinated by climate and retrofit scenarios.

Author Contributions: Conceptualization, A.T. and D.H.-A.; methodology, L.H. and D.H.-A.; data collection and analysis, L.H.; supervision, A.T. and C.D.P.; writing-original draft preparation, L.H.; writing-review and editing, D.H.-A., C.D.P. and A.T. All authors have read and agreed to the published version of the manuscript.

Funding: This research was funded by Thematic Scholarship "Energy Retrofit of Historic Buildings", grant number 32b-T4 and The APC was funded by Politecnico di Milano.

Conflicts of Interest: The authors declare no conflict of interest.

\section{References}

1. Pachauri, R.K.; Allen, M.R.; Barros, V.R.; Broome, J.; Cramer, W.; Crist, R.; Church, J.A. Climate Change 2014 Synthesis Report; Intergovernmental Panel on Climate Change (IPCC): Geneva, Switzerland, 2015.

2. EEA. Climate Change, Impacts and Vulnerability in Europe 2016: An Indicator-Based Report; European Environment Agency: Luxembourg, 2017.

3. Gandini, A.; Garmendia, L.; San Mateos, R. Towards sustainable historic cities: Adaptation to climate change risks. Entrep. Sustain. Issues 2017, 4, 319-327. [CrossRef]

4. Curtis, R.; Hunnisett Snow, J. Short Guide-Climate Change Adaptation for Traditional Buildings; Historic Environment Scotland: Edinburgh, UK, 2016.

5. Sabbioni, C.; Brimblecombe, P.; Cassar, M. The Atlas of Climate Change Impact on European Cultural Heritage: Scientific Analysis and Management Strategies; Anthem Press: London, UK, 2010.

6. Climate for Culture. Available online: https://www.climateforculture.eu/ (accessed on 24 April 2020).

7. Nano-Systems for the Conservation of Immoveable and Moveable Polymaterial Cultural Heritage in a Changing Environment. Available online: http://www.nanomatch-project.eu/ (accessed on 24 April 2020).

8. Parnassus-Protecting Cultural Heritage from Flood and Driven Rain. Available online: http://www.ucl.ac. uk/parnassus (accessed on 26 February 2020).

9. Adapt Northern Heritage. Available online: http://adaptnorthernheritage.interreg-npa.eu/ (accessed on 26 February 2020).

10. Troi, A. Historic buildings and city centres-The potential impact of conservation compatible energy refurbishment on climate protection and living conditions. In Proceedings of the International Conference Energy Management in Cultural Heritage, Dubrovnik, Croatia, 6-8 April 2011.

11. Atanasiu, B.; Despret, C.; Economidou, M.; Maio, J.; Nolte, I.; Rapf, O. Europe's Buildings under the Microscope, A Country-by-Country Review of the Energy Performance of Buildings; Buildings Performance Institute Europe (BPIE): Brussel, Belgium, 2011. 
12. EU. EU Buildings Database. Available online: https://ec.europa.eu/energy/eu-buildings-database_en (accessed on 1 September 2020).

13. EU. ENTRANZE-Policies to ENforce the TRAnsition to Nearly Zero Energy buildings in the EU-27. Available online: https://www.entranze.eu/ (accessed on 1 September 2020).

14. Dixit, M.K. Life cycle embodied energy analysis of residential buildings: A review of literature to investigate embodied energy parameters. Renew. Sustain. Energy Rev. 2017, 79, 390-413. [CrossRef]

15. Itard, L.; Klunder, G. Comparing environmental impacts of renovated housing stock with new construction. Build. Res. Inf. 2007, 35, 252-267. [CrossRef]

16. Merlino, K.R. [Re]evaluating significance: The environmental and cultural value in older and historic buildings. Public Hist. 2014, 36, 70-85. [CrossRef]

17. EU. Comprehensive Study of Building Energy Renovation Activities and Uptake of Nearly Zero Energy Buildings in the EU; EU: Brussel, Belgium, 2019.

18. Sesana, E.; Bertolin, C.; Gagnon, A.S.; Hughes, J.J. Mitigating Climate Change in the Cultural Built Heritage Sector. Climate 2019, 7, 90. [CrossRef]

19. Herrera, D.; Bennadji, A. A risk based methodology to assess the energy efficiency improvements in traditionally constructed buildings. ISPRS Int. Arch. Photogramm. Remote Sens. Spat. Inf. Sci. 2013, XL-5/W2, 337-342. [CrossRef]

20. Bjarløv, S.P.; Finken, G.R.; Odgaard, T. Retrofit with interior insulation on solid masonry walls in cool temperate climates-An evaluation of the influence of interior insulation materials on moisture condition in the building envelope. Proc. Energy Procedia 2015, 78, 1461-1466. [CrossRef]

21. Martínez-Molina, A.; Tort-Ausina, I.; Cho, S.; Vivancos, J.L. Energy efficiency and thermal comfort in historic buildings: A review. Renew. Sustain. Energy Rev. 2016, 61, 70-85. [CrossRef]

22. Galatioto, A.; Ciulla, G.; Ricciu, R.; Besalduch, L. Energy retrofit actions on Italian historical buildings: Energy efficiency and feasibility. A review study. In Proceedings of the South East European Conference on Sustainable Development of Energy, Water and Environment Systems, Piran, Slovenia, 15-18 June 2016.

23. Webb, A.L. Energy retrofits in historic and traditional buildings: A review of problems and methods. Renew. Sustain. Energy Rev. 2017, 77, 748-759. [CrossRef]

24. Posani, M.; Veiga, M.D.R.; de Freitas, V.P. Towards Resilience and Sustainability for Historic Buildings: A Review of Envelope Retrofit Possibilities and a Discussion on Hygric Compatibility of Thermal Insulations. Int. J. Archit. Herit. 2019. [CrossRef]

25. Lidelöw, S.; Örn, T.; Luciani, A.; Rizzo, A. Energy-efficiency measures for heritage buildings: A literature review. Sustain. Cities Soc. 2019, 45, 231-242. [CrossRef]

26. Berg, F.; Flyen, A.C.; Godbolt, Å.L.; Broström, T. User-driven energy efficiency in historic buildings: A review. J. Cult. Herit. 2017, 28, 188-195. [CrossRef]

27. Karunathilake, H.; Hewage, K.; Sadiq, R. Opportunities and challenges in energy demand reduction for Canadian residential sector: A review. Renew. Sustain. Energy Rev. 2018, 82, 2005-2016. [CrossRef]

28. EU. EN 16883 Conservation of Cultural Heritage-Guidelines for Improving the Energy Performance of Historic Buildings; Swedish Standards Institute: Stockholm, Sweden, 2017.

29. Council, E. Presidency Conclusions-Dublin 25/26 June 1990, Annex II: The Environmental Imperative; Council of the European Union: Brussel, Belgium, 1990; Volume SN 60/1/90.

30. EU. 2020 Cliamte \& Energy Package. Available online: https://ec.europa.eu/clima/policies/strategies/2020_en (accessed on 24 April 2020).

31. EU. Directive 2002/91/EU of the European Parliament and of the Council of 16 December 2002 on the Energy Performance of Buildings; EU: Brussel, Belgium, 2002.

32. EU. Directive 2010/31/EU of the European Parliament and of the Council on the Energy Performance of Buildings (Recast); EU: Brussel, Belgium, 2010.

33. EU. Directive 2012/27/EU of the European Parliament and of the Council of 25 Octorber 2012 on Energy Efficiency, Amending Directives 2009/125/EC and 2010/30/EU and Repealing Directives 2008/8/EC and 2006/32/EC; EU: Brussel, Belgium, 2012.

34. EU. Directive 2018/844 of the European Parliament and of the Council of 30 May 2018 Amending 2010/31/EU on the Energy Performance of Buildings and Directive 2012/27/EU on Energy Efficiency; EU: Brussel, Belgium, 2018.

35. Adaptation to Climate Change. Available online: https://ec.europa.eu/clima/policies/adaptation_en (accessed on 25 May 2020). 
36. EU. WHITE PAPER-Adapting to Climate Change: Towards a European Framework for Action; EU: Brussel, Belgium, 2009.

37. Climate ADAPT-Sharing Adaptation Information Across Europe. Available online: https://climate-adapt. eea.europa.eu/ (accessed on 15 May 2020).

38. EU. An EU Strategy on Adaptation to Climate Change; EU: Brussel, Belgium, 2013.

39. EU. Commission Staff Working Document-Adapting Infrastructure to Climate Change; EU: Brussel, Belgium, 2013.

40. EU. Commission Implementing Decision of 28.5.2014 on Deciding to Make a Standardisation Request to the European Standardisation Organisations Pursuant to Article 10 (1) of Regulation (EU) No 1025/2012 of the European Parliament and of the Council in Support of Implementation of the EU Strategy on Adaptation to Climate Change [COM(2013) 216 Final]; EU: Brussel, Belgium, 2014.

41. Berg, F.; Fuglseth, M. Life cycle assessment and historic buildings: Energy-efficiency refurbishment versus new construction in Norway. J. Archit. Conserv. 2018, 24, 152-167. [CrossRef]

42. Norrström, H. Sustainable and balanced energy efficiency and preservation in our built heritage. Sustainability 2013, 5, 2623-2643. [CrossRef]

43. Weyr, J.; Kalný, R.; Hirš, J. Impact of IPPC Scenarios on indoor environment quality of historic buildings. Proc. E3S Web Conf. 2019, 111, 03054. [CrossRef]

44. Karimpour, M.; Belusko, M.; Xing, K.; Boland, J.; Bruno, F. Impact of climate change on the design of energy efficient residential building envelopes. Energy Build. 2015, 87, 142-154. [CrossRef]

45. Dodoo, A.; Gustavsson, L.; Bonakdar, F. Effects of Future Climate Change Scenarios on Overheating Risk and Primary Energy Use for Swedish Residential Buildings. Energy Procedia 2014, 61, 1179-1182. [CrossRef]

46. Wang, H.; Chen, Q. Impact of climate change heating and cooling energy use in buildings in the United States. Energy Build. 2014, 82, 428-436. [CrossRef]

47. Li, D.H.W.; Liu, Y.; Lam, J.C. Impact of climate change on energy use in the built environment in different climate zones-A review. Energy 2012, 42, 103-112. [CrossRef]

48. Bai, L.; Wang, S. Definition of new thermal climate zones for building energy efficiency response to the climate change during the past decades in China. Energy 2019, 170, 709-719. [CrossRef]

49. Ramon, D.; Allacker, K.; De Troyer, F.; Wouters, H.; van Lipzig, N.P.M. Future heating and cooling degree days for Belgium under a high-end climate change scenario. Energy Build. 2020, 216. [CrossRef]

50. Janković, A.; Podraščanin, Z.; Djurdjevic, V. Future climate change impacts on residential heating and cooling degree days in Serbia. Idojaras 2019, 123, 351-370. [CrossRef]

51. Zhai, Z.J.; Helman, J.M. Implications of climate changes to building energy and design. Sustain. Cities Soc. 2019, 44, 511-519. [CrossRef]

52. Huang, J.; Gurney, K.R. The variation of climate change impact on building energy consumption to building type and spatiotemporal scale. Energy 2016, 111, 137-153. [CrossRef]

53. Ouedraogo, B.I.; Levermore, G.J.; Parkinson, J.B. Future energy demand for public buildings in the context of climate change for Burkina Faso. Build. Environ. 2012, 49, 270-282. [CrossRef]

54. Li, M.; Cao, J.; Xiong, M.; Li, J.; Feng, X.; Meng, F. Different responses of cooling energy consumption in office buildings to climatic change in major climate zones of China. Energy Build. 2018, 173, 38-44. [CrossRef]

55. Berardi, U.; Jafarpur, P. Assessing the impact of climate change on building heating and cooling energy demand in Canada. Renew. Sustain. Energy Rev. 2020, 121. [CrossRef]

56. Tarroja, B.; Chiang, F.; AghaKouchak, A.; Samuelsen, S.; Raghavan, S.V.; Wei, M.; Sun, K.; Hong, T. Translating climate change and heating system electrification impacts on building energy use to future greenhouse gas emissions and electric grid capacity requirements in California. Appl. Energy 2018, 225, 522-534. [CrossRef]

57. Galatioto, A.; Ricciu, R.; Salem, T.; Kinab, E. Energy and economic analysis on retrofit actions for Italian public historic buildings. Energy 2019, 176, 58-66. [CrossRef]

58. Cho, H.M.; Yang, S.; Wi, S.; Chang, S.J.; Kim, S. Hygrothermal and energy retrofit planning of masonry façade historic building used as museum and office: A cultural properties case study. Energy 2020, 201. [CrossRef]

59. Mukhopadhyay, J.; Ore, J.; Amende, K. Assessing housing retrofits in historic districts in Havre Montana. Energy Rep. 2019, 5, 489-500. [CrossRef]

60. Zhao, C.; Zhang, Y.; Wang, C.C.; Hou, M.; Li, A. Recent progress in instrumental techniques for architectural heritage materials. Herit. Sci. 2019, 7, 1-50. [CrossRef]

61. Blumberga, A.; Freimanis, R.; Muizniece, I.; Spalvins, K.; Blumberga, D. Trilemma of historic buildings: Smart district heating systems, bioeconomy and energy efficiency. Energy 2019, 186, 115741. [CrossRef] 
62. Fernández-Maldonado, A.M.; Liñares Méndez, P.; Vieites Montes, E. Planning for energy efficiency in a Historic city. The case of Santiago de Compostela, Spain. J. Settl. Spat. Plan. 2016, 2016, 53-65.

63. Lai, S.; Leone, F.; Zoppi, C. Planning for the conservation of historic districts in sardinia, Italy: Strategic and energy efficiency-related issues, and an ontological approach concerning a small town. In Green Energy and Technology; Springer International Publishing: Cham, Switzerland, 2016; pp. 177-197. [CrossRef]

64. Gregório, V.; Seixas, J. Energy savings potential in urban rehabilitation: A spatial-based methodology applied to historic centres. Energy Build. 2017, 152, 11-23. [CrossRef]

65. Csoknyai, T.; Hrabovszky-Horváth, S.; Georgiev, Z.; Jovanovic-Popovic, M.; Stankovic, B.; Villatoro, O.; Szendrő, G. Building stock characteristics and energy performance of residential buildings in Eastern-European countries. Energy Build. 2016, 132, 39-52. [CrossRef]

66. Caro-Martínez, R.; Sendra, J.J. Implementation of urban building energy modeling in historic districts. Seville as case-study. Int. J. Sustain. Dev. Plan. 2018, 13, 528-540. [CrossRef]

67. Marchi, M.; Niccolucci, V.; Pulselli, R.M.; Marchettini, N. Environmental policies for GHG emissions reduction and energy transition in the medieval historic centre of Siena (Italy): The role of solar energy. J. Clean. Prod. 2018, 185, 829-840. [CrossRef]

68. Holmes, M.J.; Hacker, J.N. Climate change, thermal comfort and energy: Meeting the design challenges of the 21st century. Energy Build. 2014, 39, 802-814. [CrossRef]

69. Lee, W.V.; Steemers, K. Exposure duration in overheating assessments: A retrofit modelling study. Build. Res. Inf. 2017, 45, 60-82. [CrossRef]

70. Balaras, C.A. The role of thermal mass on the cooling load of buildings. An overview of computational methods. Energy Build. 1996, 24, 1-10. [CrossRef]

71. Verbeke, S.; Audenaert, A. Thermal inertia in buildings: A review of impacts across climate and building use. Renew. Sustain. Energy Rev. 2017, 82, 2300-2318. [CrossRef]

72. Johra, H.; Heiselberg, P. Influence of internal thermal mass on the indoor thermal dynamics and integration of phase change materials in furniture for building energy storage: A review. Renew. Sustain. Energy Rev. 2017, 69, 19-32. [CrossRef]

73. Buhagiar, V.; Jones, P. Refurbishment of historic buildings: Thermal mass modified, its influence on indoor comfort, energy efficiency and heritage value. In Proceedings of the PLEA 2011-Architecture and Sustainable Development, Conference Proceedings of the 27th International Conference on Passive and Low Energy Architecture, Louvain-la-Neuve, Belgium, 13-15 July 2011; pp. 651-654.

74. Gagliano, A.; Nocera, F.; Patania, F.; Moschella, A.; Detommaso, M.; Evola, G. Synergic effects of thermal mass and natural ventilation on the thermal behaviour of traditional massive buildings. Int. J. Sustain. Energy 2014, 35, 411-428. [CrossRef]

75. Pfafferott, J.; Herkel, S.; Jäschke, M. Design of passive cooling by night ventilation: Evaluation of a parametric model and building simulation with measurements. Energy Build. 2003, 35, 1129-1143. [CrossRef]

76. Chen, Y.; Tong, Z.; Malkawi, A. Investigating natural ventilation potentials across the globe: Regional and climatic variations. Build. Environ. 2017, 122, 386-396. [CrossRef]

77. Blondeau, P.; Spérandio, M.; Allard, F. Night ventilation for building cooling in summer. Sol. Energy 1997, 61, 327-335. [CrossRef]

78. Shaviv, E.; Yezioro, A.; Capeluto, I.G. Thermal mass and night ventilation as passive cooling design strategy. Renew. Energy 2001, 24, 445-452. [CrossRef]

79. Gagliano, A.; Patania, F.; Nocera, F.; Signorello, C. Assessment of the dynamic thermal performance of massive buildings. Energy Build. 2014, 72, 361-370. [CrossRef]

80. Coley, D.; Kershaw, T. Changes in internal temperatures within the built environment as a response to a changing climate. Build. Environ. 2010, 45, 89-93. [CrossRef]

81. Tink, V.; Porritt, S.; Allinson, D.; Loveday, D. Measuring and mitigating overheating risk in solid wall dwellings retrofitted with internal wall insulation. Build. Environ. 2018, 141, 247-261. [CrossRef]

82. Nguyen, J.L.; Schwartz, J.; Dockery, D.W. The relationship between indoor and outdoor temperature, apparent temperature, relative humidity, and absolute humidity. Indoor Air 2014, 24, 103-112. [CrossRef] [PubMed]

83. Kramer, R.; van Schijndel, J.; Schellen, H. Inverse modeling of simplified hygrothermal building models to predict and characterize indoor climates. Build. Environ. 2013, 68, 87-99. [CrossRef] 
84. Huijbregts, Z.; Kramer, R.P.; Martens, M.H.J.; van Schijndel, A.W.M.; Schellen, H.L. A proposed method to assess the damage risk of future climate change to museum objects in historic buildings. Build. Environ. 2012, 55, 43-56. [CrossRef]

85. Lankester, P.; Brimblecombe, P. The impact of future climate on historic interiors. Sci. Total Environ. 2012, 417-418, 248-254. [CrossRef]

86. Rajčić, V.; Skender, A.; Damjanović, D. An innovative methodology of assessing the climate change impact on cultural heritage. Int. J. Archit. Herit. 2018, 12, 21-35. [CrossRef]

87. Yildiz, Y. Impact of climate change on passive design strategies. Proc. Inst. Civ. Eng. Eng. Sustain. 2015, 168, 173-181. [CrossRef]

88. Escandón, R.; Suárez, R.; Sendra, J.J.; Ascione, F.; Bianco, N.; Mauro, G.M. Predicting the impact of climate change on thermal comfort in a building category: The Case of Linear-type Social Housing Stock in Southern Spain. Energies 2019, 12, 2238. [CrossRef]

89. Peacock, A.D.; Jenkins, D.P.; Kane, D. Investigating the potential of overheating in UK dwellings as a consequence of extant climate change. Energy Policy 2010, 38, 3277-3288. [CrossRef]

90. Nghana, B.; Tariku, F. Phase change material's (PCM) impacts on the energy performance and thermal comfort of buildings in a mild climate. Build. Environ. 2016, 99, 221-238. [CrossRef]

91. Barbosa, R.; Vicente, R.; Santos, R. Climate change and thermal comfort in Southern Europe housing: A case study from Lisbon. Build. Environ. 2015, 92, 440-451. [CrossRef]

92. Pretelli, M.; Fabbri, K. New Concept of Historical Indoor Microclimate-Learning From the Past for a More Sustainable Future. Procedia Eng. 2016, 161, 2173-2178. [CrossRef]

93. Milone, D.; Peri, G.; Pitruzzella, S.; Rizzo, G. Are the Best Available Technologies the only viable for energy interventions in historical buildings? Energy Build. 2015, 95, 39-46. [CrossRef]

94. Ciulla, G.; Galatioto, A.; Ricciu, R. Energy and economic analysis and feasibility of retrofit actions in Italian residential historical buildings. Energy Build. 2016, 128, 649-659. [CrossRef]

95. Kočí, V.; Maděra, J.; Černý, R. Computational assessment of energy efficiency and hygrothermal performance of retrofitted historical building envelopes. In Proceedings of the Energy and Sustainability; Chelsea Green Publishing: Chelsea, VT, USA, 2015; pp. 185-196.

96. Cirami, S.; Evola, G.; Gagliano, A.; Margani, G. Thermal and Economic Analysis of Renovation Strategies for a Historic Building in Mediterranean Area. Buildings 2017, 7, 60. [CrossRef]

97. Stazi, F.; Vegliò, A.; Perna, C.D.; Munafò, P. Experimental comparison between three different traditional wall constructions and dynamic simulations to identify optimal thermal insulation strategies. Energy Build. 2013, 60, 429-441. [CrossRef]

98. Huws, H.; Jankovic, L. Implications of climate change and occupant behaviour on future energy demand in a zero carbon house. In Proceedings of the BS 2013: 13th Conference of the International Building Performance Simulation Association, Chambéry, France, 26-28 August 2013; pp. 1357-1364.

99. D'Ayala, D.; Aktas, Y.D. Moisture dynamics in the masonry fabric of historic buildings subjected to wind-driven rain and flooding. Build. Environ. 2016, 104, 208-220. [CrossRef]

100. Marincioni, V.; Altamirano, H. Effect of orientation on the hygrothermal behaviour of a capillary active internal wall insulation system. In Proceedings of the 10th Nordic Symposium of Building Physics, Lund, Sweden, 15-19 June 2014.

101. Ge, H.; Baba, F. Dynamic effect of thermal bridges on the energy performance of a low-rise residential building. Energy Build. 2015, 105, 106-118. [CrossRef]

102. Cavalagli, N.; Kita, A.; Castaldo, V.L.; Pisello, A.L.; Ubertini, F. Hierarchical environmental risk mapping of material degradation in historic masonry buildings: An integrated approach considering climate change and structural damage. Constr. Build. Mater. 2019, 215, 998-1014. [CrossRef]

103. Erkal, A.; D'Ayala, D.; Sequeira, L. Assessment of wind-driven rain impact, related surface erosion and surface strength reduction of historic building materials. Build. Environ. 2012, 57, 336-348. [CrossRef]

104. Abuku, M.; Janssen, H.; Roels, S. Impact of wind-driven rain on historic brick wall buildings in a moderately cold and humid climate: Numerical analyses of mould growth risk, indoor climate and energy consumption. Energy Build. 2009, 41, 101-110. [CrossRef]

105. Johansson, P.; Geving, S.; Hagentoft, C.E.; Jelle, B.P.; Rognvik, E.; Kalagasidis, A.S.; Time, B. Interior insulation retrofit of a historical brick wall using vacuum insulation panels: Hygrothermal numerical simulations and laboratory investigations. Build. Environ. 2014, 79, 31-45. [CrossRef] 
106. Nik, V.M.; Mundt-Petersen, S.O.; Kalagasidis, A.S.; De Wilde, P. Future moisture loads for building facades in Sweden: Climate change and wind-driven rain. Build. Environ. 2015, 93, 362-375. [CrossRef]

107. Budaiwi, I.; Abdou, A. Impact of indoor air conditions and solar radiation on moisture accumulation within multi-layer non-cavity walls. J. Therm. Envel. Build. Sci. 1999, 23, 123-144. [CrossRef]

108. Arumägi, E.; Pihlak, M.; Kalamees, T. Reliability of interior thermal insulation as a retrofit measure in historic wooden apartment buildings in cold climate. Proc. Energy Procedia 2015, 78, 871-876. [CrossRef]

109. Havinga, L.; Schellen, H. The impact of convective vapour transport on the hygrothermal risk of the internal insulation of post-war lightweight prefab housing. Energy Build. 2019, 204. [CrossRef]

110. Lourenço, P.B.; Luso, E.; Almeida, M.G. Defects and moisture problems in buildings from historical city centres: A case study in Portugal. Build. Environ. 2006, 41, 223-234. [CrossRef]

111. Haldi, F. Predicting the risk of moisture induced damages on the building envelope using stochastic models of building occupants' behaviour. Proc. Energy Procedia 2015, 14, 1377-1382. [CrossRef]

112. Wessberg, M.; Vyhlídal, T.; Broström, T. A model-based method to control temperature and humidity in intermittently heated massive historic buildings. Build. Environ. 2019, 159. [CrossRef]

113. Portal, N.W.; van Schijndel, A.W.M.; Kalagasidis, A.S. The multiphysics modeling of heat and moisture induced stress and strain of historic building materials and artefacts. Build. Simul. 2014, 7, 217-227. [CrossRef]

114. Ganguly, S.; Ahmed, A.; Wang, F. Optimised building energy and indoor microclimatic predictions using knowledge-based system identification in a historical art gallery. Neural Comput. Appl. 2020, 32, 3349-3366. [CrossRef]

115. Su, B. Prevention of winter mould growth in housing. Archit. Sci. Rev. 2006, 49, 385-390. [CrossRef]

116. Hagentoft, C.E.; Kalagasidis, A.S. Mold growth control in cold attics through adaptive ventilation: Validation by field measurements. In Proceedings of the 11th International Conference on Thermal Performance of the Exterior Envelopes of Whole Buildings, Clearwater, FL, USA, 5-9 December 2010.

117. Nik, V.M.; Sasic Kalagasidis, A.; Kjellström, E. Assessment of hygrothermal performance and mould growth risk in ventilated attics in respect to possible climate changes in Sweden. Build. Environ. 2012, 55, 96-109. [CrossRef]

118. Kehl, D.; Ruisinger, U.; Plagge, R.; Grunewald, J. Wooden Beam Ends in Masonry with Interior Insulation-A Literature Review and Simulation on Causes and Assessment of Decay. In Proceedings of the 2nd Central European Symposium on Building Physics, Vienna, Austria, 9-11 September 2013.

119. Odgaard, T.; Bjarløv, S.P.; Rode, C. Interior insulation-Experimental investigation of hygrothermal conditions and damage evaluation of solid masonry façades in a listed building. Build. Environ. 2018, 129, 1-14. [CrossRef]

120. Zhou, X.; Derome, D.; Carmeliet, J. Hygrothermal modeling and evaluation of freeze-thaw damage risk of masonry walls retrofitted with internal insulation. Build. Environ. 2017, 125, 285-298. [CrossRef]

121. Biseniece, E.; Žogla, G.; Kamenders, A.; Purvinš, R.; Kašs, K.; Vanaga, R.; Blumberga, A. Thermal performance of internally insulated historic brick building in cold climate: A long term case study. Energy Build. 2017, 152, 577-586. [CrossRef]

122. Toman, J.; Vimmrová, A.; Černý, R. Long-term on-site assessment of hygrothermal performance of interior thermal insulation system without water vapour barrier. Energy Build. 2009, 41, 51-55. [CrossRef]

123. Scheffler, G.; Grunewald, J. Material development and optimisation supported by numerical simulation for a capillary-active inside insulation material. In Proceedings of the Second international conference on building physics, Leuven, Belgium, 14-18 September 2003.

124. Vereecken, E.; Roels, S. A comparison of the hygric performance of interior insulation systems: A hot box-cold box experiment. Energy Build. 2014, 80, 37-44. [CrossRef]

125. Klõšeiko, P.; Arumägi, E.; Kalamees, T. Hygrothermal performance of internally insulated brick wall in cold climate: Field measurement and model calibration. In Proceedings of the 2nd Central European Symposium on Building Physics, Vienna, Austria, 9-11 September 2013.

(C) 2020 by the authors. Licensee MDPI, Basel, Switzerland. This article is an open access article distributed under the terms and conditions of the Creative Commons Attribution (CC BY) license (http://creativecommons.org/licenses/by/4.0/). 